\title{
Study on the Application of Participatory Case Teaching in Business Administration of Undergraduate Course
}

\author{
Jingling Chen \\ Business College \\ Yangzhou University \\ Yangzhou, China \\ jing_ling_chen@163.com
}

\begin{abstract}
In view of the existing case teaching problems in business administration of undergraduate course, the article puts forward the application method of participatory case teaching. The participatory case teaching can not only helps students improve their ability to solve practical problems, but also make up for the lack of practical experience of Chinese teachers, which will make great improvement both in teaching and in learning.
\end{abstract}

Keywords-participatory case teaching; major in business administration; undergraduate course

\section{INTRODUCTION}

Business administration has reached a consensus on the importance of case teaching in academic circles, but case teaching only has been successfully applied in MBA. Because of the difference of the teaching object, it should be different in the domestic business administration of undergraduate course. the author has been exploring some practical ways of the participatory case teaching in the years of professional teaching.

\section{THE EXISTING PROBLEM OF CASE TEACHING IN UNDERGRADUATE BUSINESS ADMINISTRATION}

A. We are Lack of a Complete Local Case Database Which Also Should Keep up with the Times

At present, it is popular to introduce cases from abroad in business administration courses. But, in the teaching we found, the description methods and way of thinking are quite different between abroad cases and local cases. Moreover, enterprises from local and abroad have lots of differences in the social background and political environment, which leads to less generality between Chinese and foreign cases. So it is inappropriate to apply foreign cases to home cases when we are teaching business management professional of undergraduate course. In the few domestic cases, these cases too 'classic', and can not meet the time requirements. At the same time, most belong to the incomplete cases, which have only the case description and no suggestions to solve the problems. In addition, most of cases of the industrial and commercial management are based on MBA education. The cases which are suitable to undergraduate course are rare.

\section{B. Case Teaching Teachers Lack Relevant Practical Experience}

High practical quality of teachers are required in the school offers courses of business administration abroad that teachers must have practice experience of business or management, especially the professional degree education, such as MBA, EMBA. But the teachers for Chinese undergraduates are the college graduates majoring in management, who have higher theoretical level, but few work experience in enterprises. Therefore, they tend to focus on the systematic and integrity in theory, but lack of the pertinence and inspiration in case teaching.

\section{The Enthusiasm is not High That Students Participate in Case Teaching}

There are many reasons for students' low participation in case teaching, for example, the cases that have been chosen are old and aren't able to keep up with times. Students, sometimes even including teachers, are not familiar with the content. Student performance can not be accurately and objectively assess in the case' discussion, etc. And at the same time we must admit the truth that, compared with foreign students, Chinese students are accustomed to listen and then to remember the teaching knowledge. Students' silence make case teaching fail to achieve the desired effect.

\section{THE CONNOTATION AND SIGNIFICANCE OF PARTICIPATORY CASE TEACHING}

\section{A. The Connotation of Participatory Case Teaching}

In the case of participatory teaching is different from case teaching of the general sense. Participatory case assumes that under the guidance of the teachers students can take initiative way to acquire knowledge and access to more affective knowledge than study in the tradition and passive way. it has significant characteristics in participation role, the way of case retrieve, the form of organization in case discussion. Students are placed in the center of teaching activities in participatory case teaching, from the case preparation, organization of case teaching to the evaluation of teaching effect. This kind of case teaching cannot do without the students widely involved in the whole process, and the role of the teacher is more like the band's command teachers in the case discussion. 
Though the method of participatory case teaching case in undergraduate professional courses of business management and MBA case teaching are similar, there are still some differences. First of all, the object of teaching is quite different. Most MBA students have practical working experience, while the general undergraduate students depend mostly on theory from books and lack of practical work experience. In order to make up for this deficiency, participatory case teaching emphasizes the first-hand materials through field research before finishing the whole form of case materials, which highlight the practice of case teaching. The charm of case is pacticality. Participatory case teaching requires students to go out of school, to participate in social practice activities, to gain the case in social practice. Thus, the source of in participatory case teaching are more rich.

\section{B. The Significance of Participatory Case Teaching}

Participatory case teaching helps to fully mobilize the enthusiasm of the students, to enhance their ability to solve practical problems. Volunteer team is conducive to give full play to the initiative, and often the competition between teams can reach the effect to fight for the honor. So participatory case teaching can be completed smoothly without mobilization. In addition, the biggest problem encountered is that college graduates lack of work experience and lack of the ability required to solve practical problems. Participatory case teaching can bridge students between school and society. Through participation in various activities of social practice students can better contact with society, understand society, know the society.

Participatory case teaching helps to enrich their teaching experience. The teacher is no longer the center in participatory case teaching. Their work of which are back from the stage to behind the scenes. Compared with the traditional case teaching, participatory case teaching put forward higher requirements for teachers that teachers need to update their knowledge. The time has gone forever that they only need to pass the knowledge they have learnt onto their students. Participatory case teaching provides a platform for the rich experience of teaching. They can combine their research with their case teaching. On the one hand, the case teaching can accumulation data which can lay the foundation for the application research projects, on the other hand, ideological spark in discussion collision can provide ideas for scientific research.

\section{THE APPLICATION OF THE PARTICIPATORY CASE TEACHING}

\section{A. The Preparation of Participatory Case Teaching}

At present, it is not high time to make full implementation of the participatory case teaching in every course during the undergraduate business administration courses teaching. Considering knowledge accumulation, we can arrange in the high grade two to three weeks when teaching some professional elective course. We can announce the case teaching requirements and evaluation methods to the class in advance, mainly including the contents of case teaching, the approach of forming team, the way of examination, etc. The content of participatory case teaching should obey to the teaching aim, which should point to the emphases and difficulties to realize the teaching goal. Students involve in participatory case teaching in the forms of teams, generally 5 to 6 students as a group, and each group should choose a team leader, who is responsible not only for the member division and coordination in the work, but the members of the assessment as well.

It is an important content for participatory case teaching to obtain case through participation in various activities of social practice. As each group obtain its case through participating in social practice, each group is required to complete social practice in the extracurricular time. Social practice activities including investigation and interview activities can be carried out in extracurricular time, and also in winter and summer vacation social. Social practice in summer vacation generally need to form teams which can be led by specialized teachers and supported by special funds. Intensive teaching practice generally requires going on social investgation, and then writing a report on it. Each group should write cases based on materials obtaining through the social practices. Then teachers set up case database for participatory case teaching by choosing those cases which can reflect the teaching objective and can be the representative ones. Furthermore we should go on a dynamic management of the case bases, timely updating those cases which are no longer viable.

\section{B. The Organization of Participatory Case Teaching}

Participatory case teaching is going on in teams. Each team should create a scenario in the help of multimedia, and complete the task of case analysis in limited time. In order to improve the effect of case discussion, the case shows should preferably reflect the key problems. For example, for retrospective case we can mainly discuss why not take other measures, while for ongoing case we can investigate the selection of possible actions. Case discussion requires students to listen carefully, respect each other's opinions, and learn to evaluate the contributions of others in the course of the discussion when strengthening their thinking and effective communication skills.

The effect of participatory case teaching depends on the degree of exchange between teachers and students. Therefore, we can learn some approaches and experiences from the case teaching of MPA and television talk shows such as CCTV financial channel "dialogue" column to create an active atmosphere of case discussion and to strengthen the interaction between teachers and students. The participatory teaching emphasizes the performance of students which are the center of the whole process, which doesn't mean weaken the role of teachers, on the contrary it put forward higher requirements for the teachers involved. Similar to the host on TV, only those teachers can mobilize the enthusiasm of students to participate in the case teaching who are profound and can show the wit and humor from time to time.

In view of the present situation of the teaching staff of industrial and commercial management, we can improve the teaching quality of the staff by adopting the approach of 'going out, coming in'. 'Going out' is to encourage the teachers to go on transverse scientific research by the way of entering enterprises, to led the students to participate in all kinds of social practices, to do consulting work for companies, so that 
they can accumulate more experiences in these activities. 'coming in' is to hire experienced persons in charge of the enterprise as part-time teachers, not only in this way can let students understand the society, but also helps to strengthen communication between university and enterprise so as to suply more practice opportunities for students.

\section{The Evaluation Participation Case Teaching}

The evaluation system of participatory case teaching consists evaluation subject, evaluation index and index weight. The evaluation subject of participatory case teaching subjects should include teachers and students. The final result is the average score of the teacher and the other team according to the rating criteria. The evaluation indicators include the integrity, innovation of the case, the accuracy of expression, the cooperation of teamwork, and so on. The weight of index reflect the importance of an index in the whole index system. It is helpful to improve the enthusiasm of students to participate in the case teaching when we improve the evaluation system of participation case teaching.

\section{REFERENCES}

[1] Golich Vicki L. The ABCs of Case Teaching [J]. International Studies Perspectives, 2000 (1)

[2] Ren Mingchuan. the 'form' and 'soul' of Harvard case teaching [J]. China University teaching, 2008 (4) 